\title{
Penerapan Teknik Akupresur Untuk Ibu Menyusui Dengan Menggunakan Multimedia Berbasis Pembelajaran Berbantuan Komputer (Cal)
}

\author{
Article Info \\ Article history: \\ Received 23 February 2020 \\ Revised 25 March 2020 \\ Accepted 01 April 2020 \\ Keywords: \\ Computer Assisted Learning \\ (CAL), Multimedia, Acupressure \\ Massage
}

\begin{abstract}
One of the causes of the increase in Infant Mortality Rate (IMR) is the decrease factor in exclusive breastfeeding to infants. Based on the Statistics Center (BPS) in 2016 covering $49.51 \%$ of infants in Indonesia who received exclusive breastfeeding less than 6 months. In this case, multimedia technology can be used to support government programs in Increasing Exclusive ASI Coverage Rates for Indonesian children in accordance with Government Regulation No. 33 of 2012. So, the researchers conducted research using computer-based multimedia learning assistance (CAL) technology to help support the health of several posyandu, puskesmas, and mother and child clinics in promoting exclusive breastfeeding through the Acupressure Technique which can be accessed through the release of the hormone prolactin and the hormone oxytocin in drinking mothers.
\end{abstract}

This is an open access article under the CC BY-SA license.

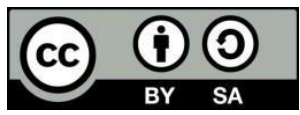

Corresponding Author:

Rimmar Siringoringo

Imelda University Medan, Information Management, Medan, Indonesia

Email Address: rimmarsiringoringo1@gmail.com

\section{Pendahuluan}

Peran penting ASI sebagai sumber nutrisi pertama bagi bayi dan merupakan makanan terbaik bagi bayi karena mengandung nutrisi lengkap yang dapat meningkatkan imunitas dan menjadi faktor pendukung tumbuh kembang bayi secara optimal selama enam bulan pertama kehidupannya [1], [2]. Zat gizi yang terkandung dalam ASI antara lain karbohidrat, lemak, protein, vitamin, mineral, dan zat-zat penunjang gizi lainnya [3]. Namun banyak ibu menyusui yang tidak dapat memproduksi ASI dengan baik karena kurang percaya diri untuk dapat menyusui bayinya, sehingga memicu penurunan hormon oksitosin yang menyebabkan ASI tidak segera keluar setelah melahirkan dan pada saat persalinan. . akhirnya mereka memilih untuk memberikan susu formula kepada bayinya [4], [5]. Susu formula tidak memiliki nutrisi yang lengkap seperti ASI sehingga tidak dapat sepenuhnya digunakan untuk memenuhi asupan gizi bayi. Hal ini menjadi salah satu penyebab meningkatnya angka kematian bayi (AKB) . Oleh karena itu, pemerintah mencanangkan program peningkatan penggunaan Air Susu Ibu (P2ASI) untuk menurunkan Angka Kematian Bayi (AKB) sesuai

Peraturan Pemerintah Nomor 33 Tahun 2012 Pasal 1 dan 2 tentang “Air Susu Ibu Eksklusif yang selanjutnya disebut ASI Eksklusif adalah ASI yang diberikan kepada bayi sejak lahir 
selama 6 (enam) bulan, tanpa menambah dan/atau menggantinya dengan makanan atau minuman lain" [6], [7]. Klinik Lingkungan Lingkungan Medan Amplas juga mencanangkan program pemerintah dalam Meningkatkan Penggunaan ASI untuk Ibu. Susu (P2ASI) dengan mensosialisasikan ASI Eksklusif melalui teknik akupresur kepada $28 \mathrm{ibu}$ hamil/menyusui melalui alat seadanya yang dibantu langsung oleh bidan Eva (pemilik puskesmas) dan 2 tenaga kesehatan. kesehatan. Melihat

Kepedulian bapak dan ibu klinik terhadap ibu hamil/ibu menyusui di lingkungannya, peneliti melakukan penelitian dengan menggunakan teknologi multimedia sebagai sarana sosialisasi kepada mereka dalam menerapkan Teknik Akupresur pada ibu hamil/ibu menyusui berbasis Computer Assisted Learning (CAL)[8]. Teknik akupresur berfungsi untuk merangsang hormon prolaktin dan oksitosin pada ibu menyusui. Akupresur sendiri merupakan suatu teknik yang digunakan sebagai pengobatan nonfarmakologis dan erat kaitannya dengan akupunktur, yang dilakukan melalui penekanan pada titik-titik tertentu pada tubuh. Namun, masih banyak orang yang belum mengetahui manfaat akupresur bagi ibu menyusui. Computer Assisted Learning (CAL) merupakan suatu strategi dalam proses belajar mengajar yang dilakukan dengan menggunakan bantuan komputer atau yang biasa disebut dengan teknologi informasi. Dengan adanya aplikasi multimedia berbasis Computer Assisted Learning (CAL) ini diharapkan dapat memberikan pemahaman dan pembelajaran tentang teknik akupresur dengan visual yang menarik, mudah dipahami, dan didukung dengan visual yang jelas [9], [10]. Namun, masih banyak orang yang belum mengetahui manfaat akupresur bagi ibu menyusui. Computer Assisted Learning (CAL) merupakan suatu strategi dalam proses belajar mengajar yang dilakukan dengan menggunakan bantuan komputer atau yang biasa disebut dengan teknologi informasi. Dengan adanya aplikasi multimedia ini berbasis Computer Assisted Learning (CAL), diharapkan dapat memberikan pemahaman dan pembelajaran tentang teknik akupresur dengan visual yang menarik, mudah dipahami, dan didukung dengan visual yang jelas [11]. Namun, masih banyak orang yang belum mengetahui manfaat akupresur bagi ibu menyusui. Computer Assisted Learning (CAL) merupakan suatu strategi dalam proses belajar mengajar yang dilakukan dengan menggunakan bantuan komputer atau yang biasa disebut dengan teknologi informasi[12]. Dengan adanya aplikasi multimedia berbasis Computer Assisted Learning (CAL) ini diharapkan dapat memberikan pemahaman dan pembelajaran tentang teknik akupresur dengan visual yang menarik, mudah dipahami, dan didukung dengan visual yang jelas . masih banyak orang yang belum mengetahui manfaat akupresur untuk ibu menyusui [13]. Computer Assisted Learning (CAL) merupakan suatu strategi dalam proses belajar mengajar yang dilakukan dengan menggunakan bantuan komputer atau yang biasa disebut dengan teknologi informasi. Dengan adanya aplikasi multimedia berbasis Computer Assisted Learning (CAL) ini diharapkan dapat memberikan pemahaman dan pembelajaran tentang teknik akupresur dengan visual yang menarik, mudah dipahami, dan didukung dengan visual yang jelas. masih banyak orang yang belum mengetahui manfaat akupresur untuk ibu menyusui. Computer Assisted Learning (CAL) merupakan suatu strategi dalam proses belajar mengajar yang dilakukan dengan menggunakan bantuan komputer atau yang biasa disebut dengan teknologi informasi. Dengan adanya aplikasi multimedia berbasis Computer Assisted Learning (CAL) ini diharapkan dapat memberikan pemahaman dan pembelajaran tentang teknik akupresur dengan visual yang menarik, mudah dipahami, dan didukung dengan visual yang jelas[14].

\section{Metode}

Research and Development (R\&D) sendiri digunakan sebagai metode penelitian dalam penelitian ini yang akan menghasilkan produk media pembelajaran berbasis computerassisted learning (CAL) teknik akupresur untuk ibu hamil/menyusui. apa yang peneliti 


\section{Rimmar Siringoringo}

doi.org/10.54209/jatilima.v2i1.141

lakukan meliputi potensi dan masalah, pengumpulan data, desain produk, validasi desain, revisi desain, pengujian produk, analisis, dan pelaporan.

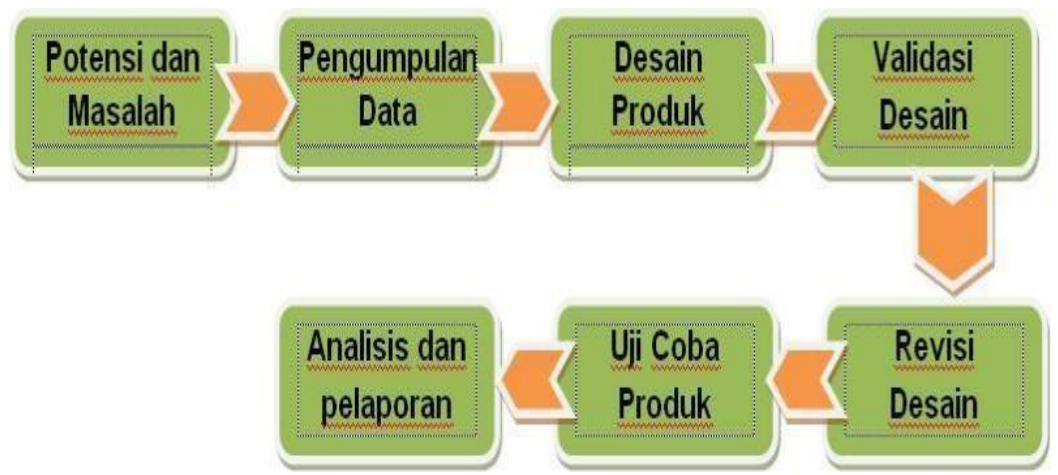

Gambar 1. Metode Penelitian dan Pengembangan (R\&D)

\section{Analisis dan Diskusi}

Masalah dalam hal ini adalah mendeskripsikan masalah secara detail sehingga pembahasan menjadi lebih jelas dan hasil penelitian sesuai dengan sasaran. Berikut ini adalah desain multimedia teknik akupresur:

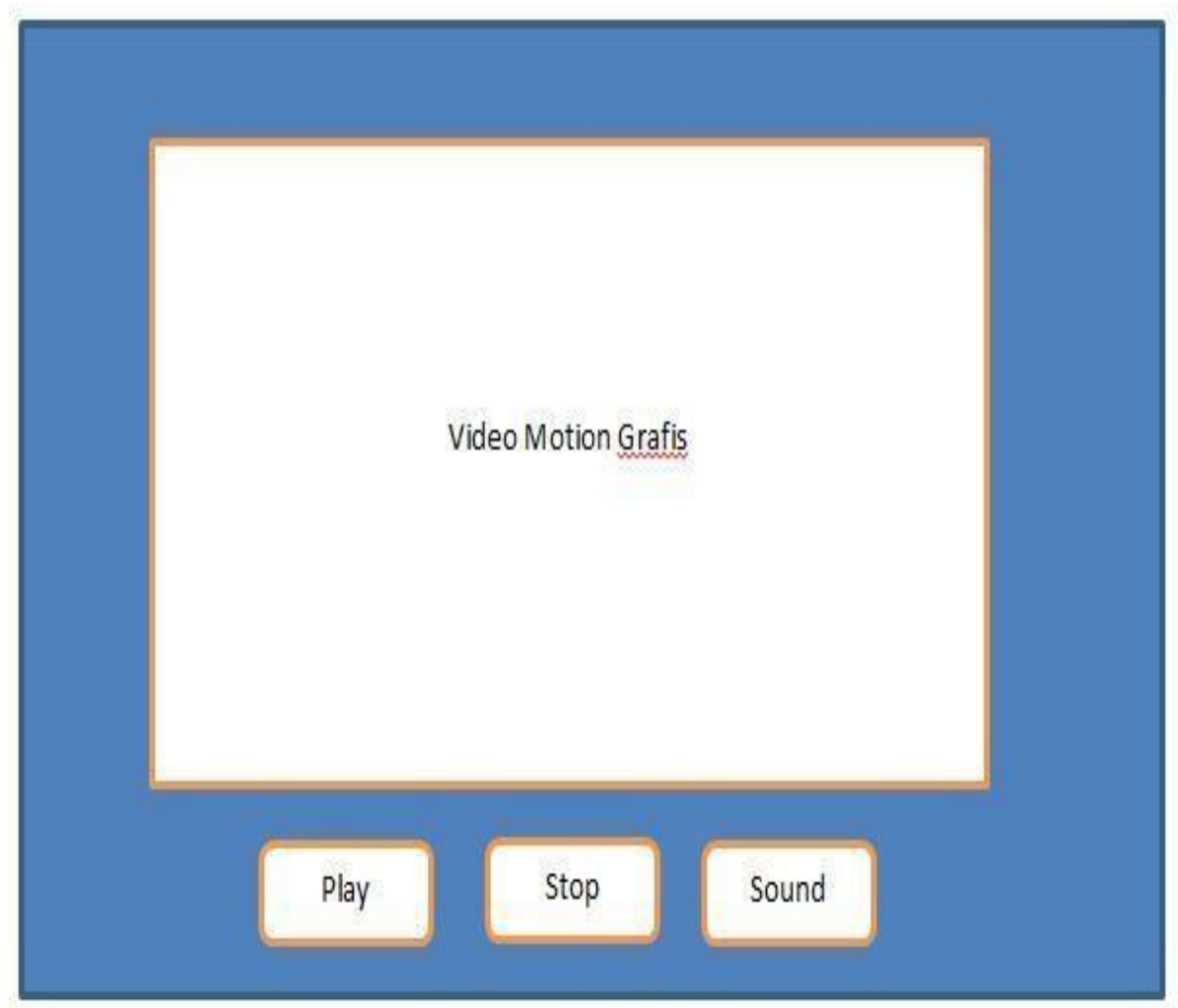

Gambar 2. Rancangan Desain Tampilan Multimedia Teknik Akupresur

Draf ini terdiri dari kolom video grafik gerak yang akan menampilkan demonstrasi gerak teknik akupresur berbasis multimedia. Lalu ada tombol play untuk memutar video, dan tombol stop untuk menjeda video. Dilengkapi dengan suara untuk audio dalam video ini. Karena video multimedia ini berbasis computer assisted learning (CAL), maka penjelasan dalam video tersebut berupa langkah-langkah melakukan teknik akupresur yang dapat dipelajari dengan mudah oleh pengguna. 


\section{Rimmar Siringoringo}

doi.org/10.54209/jatilima.v2i1.141

\section{Tampilan Video Multimedia Teknik Akupresur}

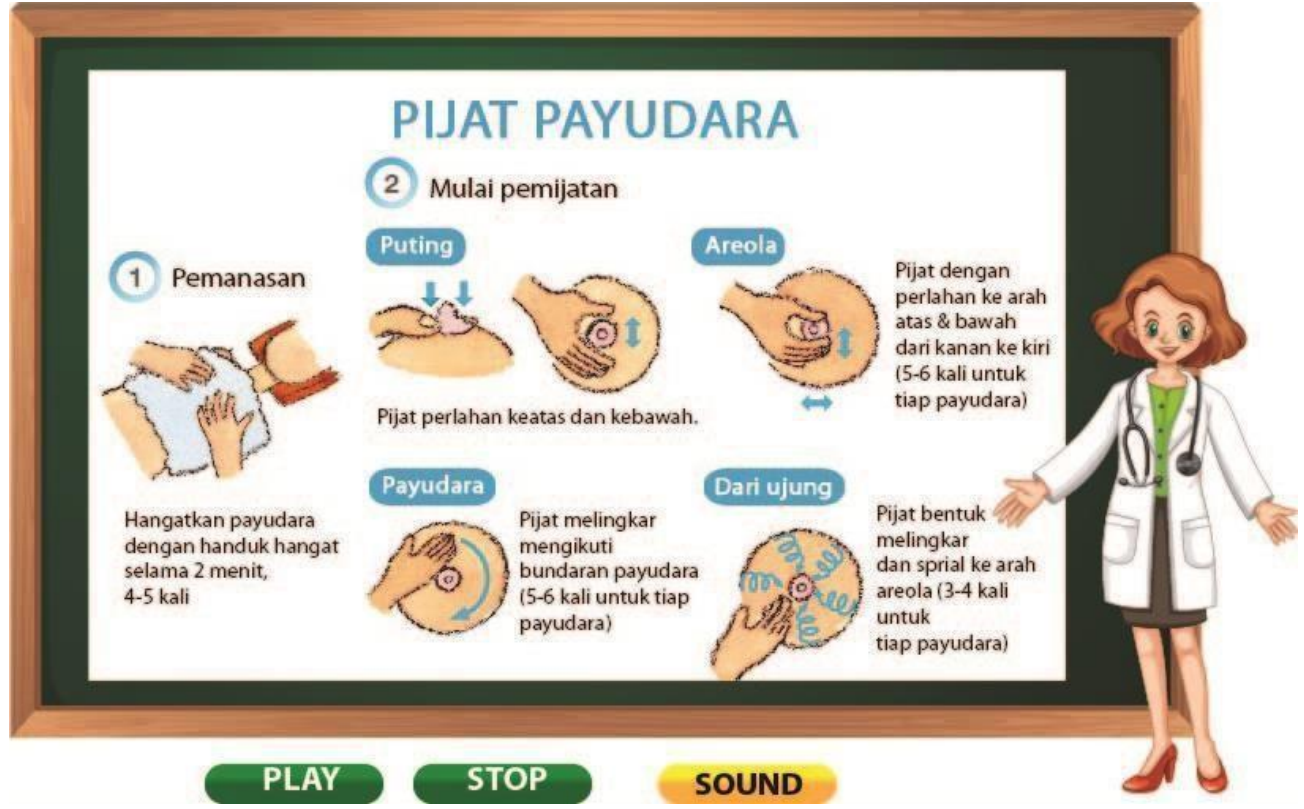

Gambar 3. Tampilan Video Teknik Akupresur

Pada tampilan ini menjelaskan tentang gerakan teknik akupresur pada payudara, teknik ini dibuat dengan gambar vektor 2 dimensi. Dilengkapi dengan fitur suara.

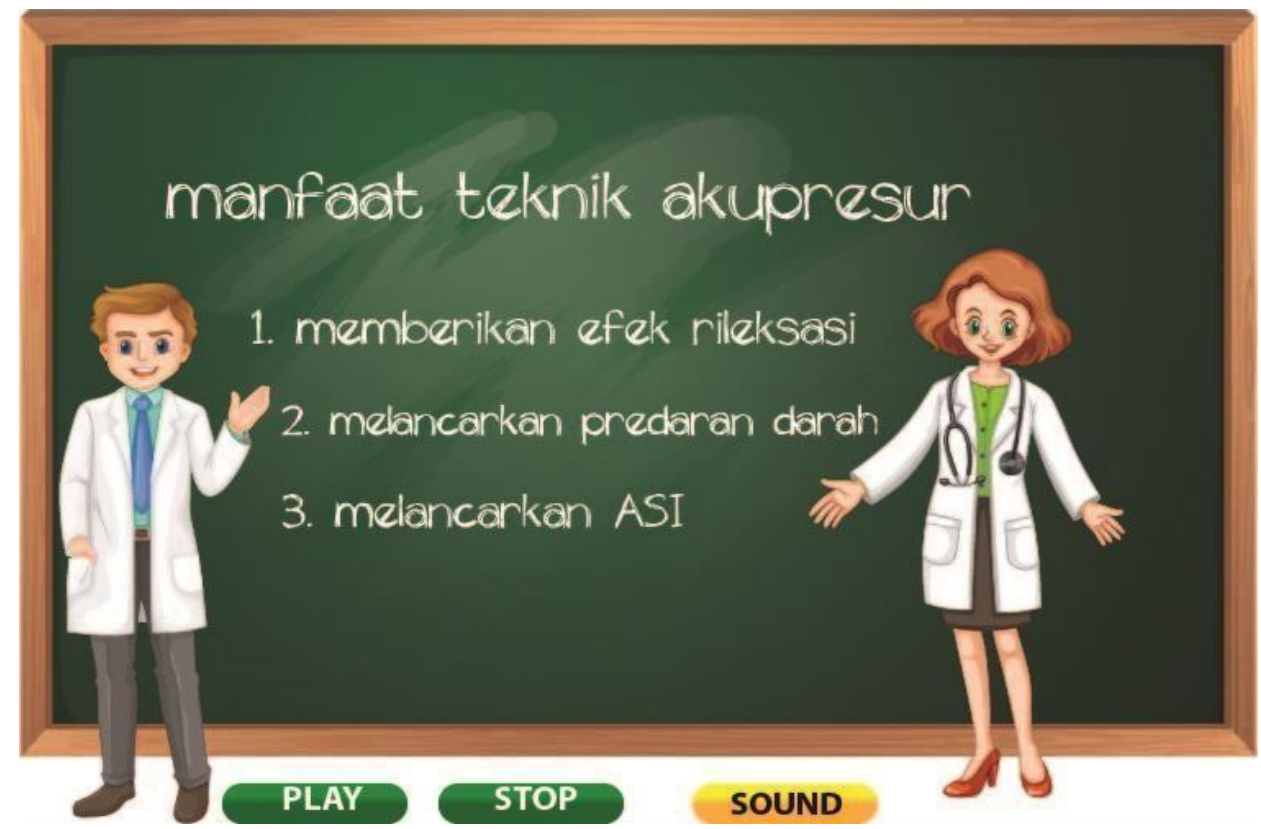

Gambar 4. Penjelasan Manfaat Teknik Pijat Akupresur Bagi Ibu Menyusui

Dalam tampilan ini, narator menjelaskan manfaat teknik akupresur untuk ibu menyusui dengan animasi tipografi jenis font Essen. Teks berjalan dalam efek gerak satu per satu. 


\section{Rimmar Siringoringo}

doi.org/10.54209/jatilima.v2i1.141

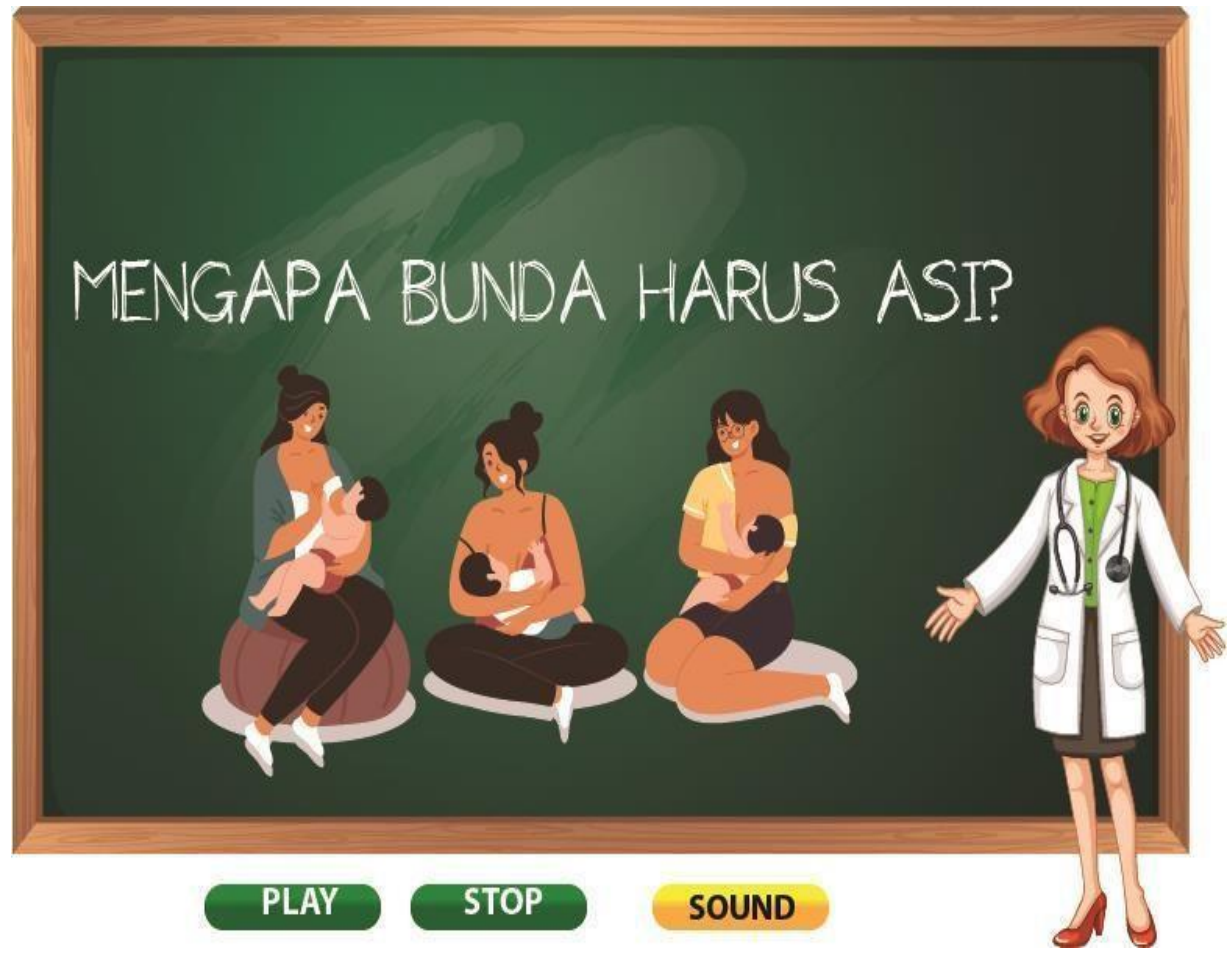

Gambar 5. Teknik Akupresur Multimedia Motion Graphic

Dalam tampilan ini ada cuplikan alasan mengapa ASI dibutuhkan. Tampilan ini menggunakan gambar grafik vektor dan menggunakan ilustrasi model yang dilengkapi dengan bentuk gerak.

\section{Kesimpulan}

Berdasarkan hasil penelitian yang dilakukan, diperoleh kesimpulan yang sesuai dengan hasil penelitian sebagai berikut : Media ajar multimedia sangat efektif dalam memberikan informasi kepada pengguna. Pengantar teknik akupresur berbasis multimedia. Pemanfaatan metode Computer Assisted Learning (CAL) menyediakan simulasi grafis berbasis komputer. Video multimedia ini sangat membantu tenaga kesehatan dan bidan dalam memberikan informasi. Teknik akupresur untuk memperlancar ASI. Metode Computer Assisted Learning (CAL) sangat membantu dalam pengembangan prototype multimedia ini.

\section{Referensi}

[1] S. Sugiarsi and T. Suryanti, "KEBIJAKAN AIR SUSU IBU (ASI) EKSKLUSIF SEBAGAI FAKTOR PENENTU POLA MENYUSUI IBU DENGAN ASI EKSLUSIF DI WILAYAH KERJA PUSKESMAS MONDOKAN SRAGEN."

[2] H. Puspasari, I. C. Nisa, H. F. Aeni, and F. Xaverius, "Pendidikan Kesehatan Asi Ekslusif dan Akupresur untuk Meningkatkan Produksi Asi di RW 10 Kelurahan Karyamulya Kecamatan Kesambi Kota Cirebon," in Call For Paper Seminar Nasional Kebidanan, 2020, vol. 1, no. 1, pp. 99-104.

[3] R. K. Wardana, N. Widyastuti, and A. Pramono, "Hubungan Asupan Zat Gizi Makro dan Status Gizi Ibu Menyusui dengan Kandungan Zat Gizi Makro pada Air Susu Ibu (ASI) di Kelurahan Bandarharjo Semarang," J. Nutr. Coll., vol. 7, no. 3, pp. 107-113, 2018.

[4] J. Anshory, I. Tanziha, A. Mappaompo, and N. M. J. Nasrah, "The Effect of Physical 
Activity (Endurance and Strength) and Sleep Management on BMI and Body Fat Children Overweight in Makassar City.," Indian J. Public Heal. Res. Dev., vol. 9, no. 10, 2018.

[5] F. Agustini, S.ST.,M.Kes, "FAKTOR-FAKTOR YANG MEMPENGARUHI PEMBERIAN ASI EKSKLUSIF DI DESA CIKUNIR WILAYAH KERJA PUSKESMAS SINGAPARNA KECAMATAN SINGAPARNA KABUPATEN TASIKMALAYA TAHUN 2014," J. Kesehat. BIDKESMAS RESPATI, vol. 1, no. 6, 2015, doi: 10.48186/bidkes.v1i6.4.

[6] A. S. I. Eksklusif, "Faktor-Faktor yang Berhubungan dengan Pemberian Air Susu Ibu Eksklusif di Wilayah Kerja Puskesmas Anggalomoare Kabupaten Konawe," J. MediLab Mandala Waluya Kendari Vol, vol. 3, no. 1, 2019.

[7] H. K. Abrar, M. Musakkir, and H. Halim, "EFEKTIVITAS PELAKSANAAN PERATURAN DAERAH KOTA MAKASSAR NOMOR 3 TAHUN 2016 TENTANG PEMBERIAN AIR SUSU IBU (ASI) EKSKLUSIF," Al-Amwal J. Islam. Econ. Law, vol. 5, no. 1, pp. 1-20, 2020.

[8] M. Wali and L. Ahmad, "Computer Assisted Learning (CAL): A Learning Support System Solution," Webology, vol. 18, no. 1, 2021, doi: 10.14704/WEB/V18I1/WEB18090.

[9] J. Chuthapisith, B. Dimambro, and G. Doody, "Effectiveness of a computer assisted learning (CAL) package to raise awareness of autism," BMC Med. Educ., vol. 9, no. 1, 2009, doi: 10.1186/1472-6920-9-12.

[10] A. Simangunsong and P. S. Hasugian, "Application of the Certainty Factor Method to Diagnose Escherichia Coli Bacteria in Refilled Drinking Water," J. Info Sains Inform. dan Sains, vol. 10, no. 1, pp. 7-12, 2020.

[11] F. Shaikh et al., "Computer-Assisted Learning Applications in Health Educational Informatics: A Review.," Cureus, vol. 9, no. 8, 2017, doi: 10.7759/cureus.1559.

[12] M. Suyanto, "Aplikasi Multimedia Pada Proses Belajar Mengajar," Karya Ilmiah Dosen. 2007.

[13] F. C. YEE, R. MUSTAFFA KAMAL, S. SHARMA, N. T. HUA, and S. K. D. JOGINDER SINGH, "Development of a Computer-Assisted Learning Courseware for Anatomy and Physiology of Swallowing," J. Sains Kesihat. Malaysia, vol. 16, no. 01, 2018, doi: 10.17576/jskm-2018-1601-21.

[14] W. B. Little, E. Artemiou, A. Conan, and C. Sparks, "Computer assisted learning: Assessment of the veterinary virtual anatomy education software IVALA "TM," Vet. Sci., vol. 5, no. 2, 2018, doi: 10.3390/vetsci5020058.

[15] Tanduklangi A, Amri C. Manajemen Sumber Daya Pembelajaran Bahasa Berbantuan Komputer: Computer Assisted Language Learning. Deepublish; 2019 Nov 1. 